Leszek Graniszewskl ${ }^{1}$

\title{
Governance w Polsce - udział organizacji pozarządowych we współrządzeniu publicznym
}

\section{Wstęp}

Współcześnie rolą i istotą administracji publicznej jest służenie społeczeństwu w ramach państwa demokratycznego, jako jeden $\mathrm{z}$ nieodzownych jego elementów obok takich elementów jak: system polityczny, prawo, gospodarka rynkowa oraz społeczeństwo obywatelskie ${ }^{2}$. Obecnie wzajemne relacje administracji i organizacji społeczeństwa obywatelskiego określa się anglosaskim terminem governance (współrządzenie). Koncepcja governance jest próbą realizacji tych teorii demokracji (partycypacyjnej, uczestniczącej), które zakładają szerszy udział obywateli w publicznym procesie decyzyjnym w powiązaniu z zasadą pomocniczości. Polega to w tym przypadku na powierzaniu zadań organizacjom społeczeństwa obywatelskiego z zachowaniem władczych uprawnień sektora publicznego w celu zagwarantowania dobra publicznego w polityce demokratycznej ${ }^{3}$. Współrządzenie ma być odpowiedzią na zwiększającą się różnorodność wartości, celów i interesów podmiotów społecznych oraz wynikiem zmiany podejścia administracji publicznej, która powinna postrzegać obywateli i ich organizacje nie tylko jako petentów i klientów, ale partnerów do współrządzenia.

Celem artykułu jest analiza możliwości zastosowania koncepcji governance (współrządzenia) w realiach polskiego systemu politycznego, szczególnie w postaci współpracy organizacji pozarządowych (w szerokim ujęciu, a więc także w odniesieniu do tradycyjnych partnerów społecznych takich jak związki zawodowe i organizacje pracodawców) z organami władzy wykonawczej. Omówione zostaną teoretyczne warianty możliwego zastosowania koncepcji governance, następnie wpływ czynników ustrojo-

1 Leszek Graniszewski, Instytut Pracy Socjalnej Uniwersytetu Pedagogicznego im. KEN w Krakowie.

$2 \mathrm{H}$. Izdebski, Introduction to public administration and administrative law, Warszawa 2006, s. 14.

3 J. Supernat, Administracja publiczna, governance i nowe publiczne zarzadzanie [w:] Prawna działalność instytucji społeczeństwa obywatelskiego, J. Blicharz, J. Boć (red.), Wrocław 2009, s. 139 i n. 
wych, politycznych i kulturowych na możliwości ograniczenia zastosowania tej koncepcji w Polsce na tle prób implementacji współrządzenia w polskich realiach systemowych.

Autor wychodzi z założenia, że formy współrządzenia wprowadzane w Polsce miały do tej pory w dużym stopniu fasadowy lub co najwyżej instrumentalny charakter, wynikający z modelu demokracji naśladowczej. Związane jest to $\mathrm{z}$ wciąż aktualną w naszym kraju skłonnością „do tworzenia instytucji fasadowych, gdyż pozór jest ważniejszy od istoty sprawy i dotarcia do sedna zagadnienia"4. Badacze zajmujący się problematyką fasadowości polskich instytucji społecznych i publicznych powołują się w tym zakresie na obserwacje A. Podgóreckiego dokonane jeszcze w okresie systemu realnego socjalizmu. Należy więc ocenić, czy tworzenie pewnych instytucji dialogu społecznego i obywatelskiego, które mieszczą się w koncepcji governance nie wynika jedynie ze skłonności do fasadowych działań nastawionych na stworzenie wyobrażenia istnienia współrządzenia $\mathrm{w}$ procesie politycznym w Polsce ${ }^{5}$.

\section{Warianty udziału obywateli w podejmowaniu decyzji przez administrację publiczną}

Alternatywne strategie udziału obywateli w procesie decyzyjnym wynikają z modelu administracji Weberowskiej oraz współcześnie nabierającego coraz większego znaczenia neoweberowskiego modelu zarządzania publicznego. W tradycyjnym modelu Weberowskiej administracji publicznej zastosowanie miała strategia proceduralizacji. W jej realizacji wychodzono z założenia, że proces polityczny polega na identyfikacji potrzeb obywateli przez partie i ruchy polityczne w procesie wyborczym i agregacji interesów, czyli formalnym i zinstytucjonalizowanym sposobie przekładania preferencji obywateli na działania podejmowane przez władzę publiczną. Zatem rola obywateli ogranicza się do udziału w wyborach, gdyż zakłada się ich ograniczoną zdolność i gotowość do aktywnej troski o dobro wspólne.

Strategia komodyfikacji zakłada skupienie się na efektywności i skuteczności państwa w wykonywaniu zadań publicznych. Włączanie obywateli w sprawy publiczne odbywa w sposób transakcyjny, czyli polega na wymianie określonych dóbr między obywatelem a państwem. Ta logika kontraktu, np. podatki w zamian za usługi publiczne, jest sednem Nowego Zarządzania Publicznego (New Public Management - NPM) ${ }^{6}$. Partnerstwo międzysektorowe w ramach nowego zarządzania publicznego wymaga od-

4 A. Zybała, Polski umysł zamknięty, „Rzeczpospolita” 2016, nr 223.

5 A. Podgórecki, Teoria społeczeństwa polskiego [w:] Przełom i wyzwanie, A. Sułek, W. Wincławski (red.), Warszawa-Toruń 1991, s. 109.

6 M. Małecka-Łyszczek, Partycypacja w ramach public governance [w:] Partycypacja społeczna w samorządzie terytorialnym, B. Dolnicki (red.), Warszawa 2014, s. 45-46. 
chodzenia od Weberowskiego modelu biurokracji, skupionej jedynie na wypełnianiu tych samych prostych zadań, poprzez przeorientowanie się na współdziałanie $\mathrm{z}$ instytucjami rynkowymi i organizacjami pozarządowymi, które dostarczają usług służących zaspokajaniu potrzeb ogółu. Wymaga to od sektora publicznego zdolności sprawnego wdrażania innowacyjnych programów publicznych trafnie diagnozujących i adresujących problemy obsługiwanej społeczności z zapewnieniem efektywnego ekonomicznie świadczenia usług publicznych ${ }^{7}$.

Natomiast governance (public governance) to wynikające ze strategii integracyjnej państwa wzajemne relacje administracji i organizacji społeczeństwa obywatelskiego, zakładające współdziałanie i wymianę zasobów. Koncepcja ta obejmuje przede wszystkim otwartość na negocjacje, wzajemną komunikację i sugerowanie w celu osiągnięcia konsensusu i wzajemnego zrozumienia, a nie tylko rządzenie poprzez bezpośredni nadzór i hierarchiczne zarządzanie. Ponadto zakłada ona wzmacnianie partycypacji i poszerzanie ilości uczestników procesów współrządzenia, którym to zjawiskom towarzyszą procesy dyfuzji kompetencji władczych w górę i w dół oraz horyzontalnej dyspersji (przesunięcia) władzy w kierunku lokalnych i globalnych podmiotów nierządowych ${ }^{8}$.

Jak wskazują B. Guy Peters i J. Pierre, governance charakteryzuje dominacja sieci - nie formalne instytucje (ang. policymaking institutions), ale amorficzny zbiór aktorów ma wpływ na to, jak dobra i usługi publiczne będą świadczone. Związane jest to z niezdolnością rządu do pełnej scentralizowanej kontroli polityki publicznej. Rządowi pozostaje jedynie wpływanie na nią w powiązaniu z umiejętnością prowadzenia negocjacji i zawierania umów z uczestnikami sieci jako równoprawnymi partnerami w trakcie procesu politycznego oraz lączenie zasobów publicznych i prywatnych (np. włączenie prywatnych spółek do realizacji programów społecznych, aby ominąć drogie i czasochłonne procedury) ${ }^{9}$.

Wśród czynników skłaniających rządzących do sięgania po praktyki współrządzenia wskazać można na:

1) zwiększającą się złożoność zadań publicznych oraz kłopoty z realizacją zobowiązań socjalnych państwa związane z kryzysem państwa opiekuńczego, co z kolei jest efektem kumulacji innych negatywnych zjawisk takich jak: kryzys gospodarczy i finansowy, kryzys demograficzny, kryzys

7 J. Blicharz, Rola partnerstwa trójsektorowego w ramach nowego zarządzania publicznego a problem biurokracji [w:] Biurokracja, J. Łukaszewicz (red.), Rzeszów 2006, s. $83-85$.

8 L. Rajca, Reformy inspirowane koncepcja wspótrządzenia (governance) w Anglii [w:] Wspótczesne wyzwania administracji rządowej i samorządowej, D. Plecka (red.), Toruń 2013, s. 368.

9 B.G. Peters, J. Pierre, Governance without government? Rethinking public administration, "Journal of Public Administration Research \& Theory” 1998, vol. 8, no. 2. 
na rynku pracy spowodowany m.in. złym systemem edukacji i przygotowania do zawodu, robotyzacją pracy itd.;

2) zmniejszenie się poziomu legitymizacji władzy publicznej wynikające z obniżającego się poziomu zaufania wobec polityków, którzy skupiają się ma marketingu politycznym (postpolityka), a nie rozwiązują problemów publicznych (co jest też obiektywnie trudne w warunkach globalizacji gospodarczej);

3) niesprawność państwa i ograniczone możliwości dyskrecjonalnego i hierarchicznego podejmowania decyzji w sferze publicznej (redefinicja władzy publicznej), co jest przejawem świadomości rozproszenia zasobów niezbędnych do kształtowania procesów społecznych, na które administracja publiczna nie ma już monopolu, będąc niejako uzależnioną od współpracy z całym wachlarzem partnerów publiczno-prywatnych. W efekcie ze względu na zmniejszającą się rolę partii politycznych rośnie znaczenie innych aktorów pozapaństwowych (korporacje, organizacje pozarządowe, grupy interesu) ze względu na zwiększające się znaczenie polityki nacisku i protestu oraz zjawisk takich jak wielocentryczność, „nowe średniowiecze", demokracja hybrydowa ${ }^{10}$.

Zgodnie z koncepcją współrządzenia skuteczniejsze działanie administracji publicznej wzmacniane jest przez otwarcie jej na demokratyzację i umożliwienie partnerom społecznym udziału w formułowaniu i implementacji polityki ${ }^{11}$. Jak zauważa L. Rajca, współrządzenie akcentuje podmiotową rolę społeczeństwa obywatelskiego w realizacji celów publicznych i co za tym idzie „zakłada zarówno wielość aktorów współuczestniczących w świadczeniu usług publicznych, jak i wpływ różnorodnych procesów na system podejmowania decyzji politycznych w państwie"12. Zatem koncepcja governance zmierza do tego, aby rządzący i administracja publiczna nie byli jedynymi kreatorami polityki publicznej, ale by byli otwarci na udział różnych aktorów pozarządowych w kształtowaniu polityki publicznej.

NPM jest ekonomiczną formą realizacji koncepcji governance, zgodnie z którą zakłada się dążenie do zwiększenia efektywności i wydajności działań na rzecz użyteczności publicznej poprzez korzystanie z mechanizmów rynkowych i korporacyjnych w celu poprawy zadowolenia obywateli z usług publicznych. W tym celu należy dążyć do decentralizacji podejmowania decyzji dotyczących obywateli. W efekcie prowadzić ma to do zwiększenia rządowych możliwości kształtowania i realizacji programów społecznych i wymuszeniu odpowiedzialności rządu za podejmowane obietnice i realizowane działania ${ }^{13}$. W ramach NPM wykorzystuje się nowe

10 Więcej na temat tych zjawisk w L. Graniszewski, Udział aktorów pozapaństwowych w rządzeniu transnarodowym, „Studia Politologiczne” 2015, vol. 27, s. 91-121.

11 A.M. Kjaer, Governance and the Urban Bureaucracy, [w:] J. Davies, D.L. Imbroscio (eds.), Theories of urban politics, Sage Publications Ltd 2009, s. 141.

12 L. Rajca, Reformy..., s. 367.

13 J. Supernat, Administracja publiczna, governance..., s. 140-141. 
metody przygotowania i realizacji polityki publicznej poprzez instrumenty pośrednie wpływania na decyzje i działania np. zachęty podatkowe, a nie władcze nakazy i zakazy (np. „proekologiczna” polityka podatkowa) ${ }^{14}$.

W ramach koncepcji governance zauważa się podstawowe różnice między sektorem publicznym i prywatnym, natomiast NPM chce zaszczepić sektorowi publicznemu wartości korporacyjne. Governance wyjaśnia procesy kształtowania polityki publicznej a NPM widzi procesy z punktu widzenia ich wyników, jak najbardziej efektywnych ${ }^{15}$. Jednakże poprawa funkcjonowania administracji może odbywać się z korzyścią dla jednostek jako konsumentów usług publicznych świadczonych przez administrację, ale kosztem jednostek jako obywateli, którzy mogą zostać odsunięci od bezpośredniego wpływu na bieg spraw publicznych nawet w swoim najbliższym otoczeniu lokalnym ${ }^{16}$.

New Public Management jest teorią organizacji, która zakłada alternatywną wobec Weberowskiej koncepcję organizowania usług publicznych, a governance jest teorią polityki, która nie jest wroga modelowi Weberowskiemu, ale zwraca uwagę bardziej na relacje między rządem i społeczeństwem, aby wyjaśnić, jak usługi publiczne mogą być świadczone lepiej. Zakłada utrzymanie rządowej kontroli nad usługami publicznymi, ale z przyznaniem większej roli w kształtowaniu polityki publicznej sektorowi prywatnemu. Natomiast NPM zakłada zasadniczą zmianę modelu funkcjonowania sektora publicznego i zastępowanie dotychczasowego modelu Weberowskiej administracji publicznej nowymi modelami publicznego zarządzania.

Wspólne w NPM i governance jest założenie, że rząd powinien raczej sterować, czyli ustalać główne cele polityczne, niż skupiać się na bezpośrednim działaniu służącym ich realizacji. Administracja może bowiem brać udział w wypracowywaniu decyzji bezpośrednio albo pośrednio - poprzez np. mechanizm kolibracji umożliwiający udział aktorów społecznych ${ }^{17}$. $\mathrm{W}$ tym celu stwarza się prawne mechanizmy wspierania pozycji jednych podmiotów (interesariuszy), aby zrównoważyć ich pozycję względem podmiotów silniejszych, np. poprzez kształtowanie równowagi między pracownikami i pracodawcami (negocjacje zbiorowe, Rada Dialogu Społecznego, rady działalności pożytku publicznego). W przypadku dialogu społecznego i obywatelskiego instytucje państwa wprowadzają rozwiązania instytucjo-

14 J. Rotko, Ekologiczna polityka podatkowa w RFN [w:] Księga Jubileuszowa Profesora Marka Mazurkiewicza: studia z dziedziny prawa finansowego, prawa konstytucyjnego i ochrony środowiska, R. Masalski (red.), Wrocław 2001, s. 413 i n.

15 B.G. Peters, J. Pierre, Governance...

16 J. Supernat, Administracja publiczna w świetle koncepcji New Public Management [w:] Jednostka, państwo, administracja - nowy wymiar. Międzynarodowa Konferencja Naukowa, Olszanica 23-26 maja 2004 r., E. Ura (red.), Rzeszów 2004, s. 12.

17 Por. A. Dunsire, Przechylanie szal: autopoieza i rządzenie, „Zarządzanie Publiczne" 2007, nr 2, s. 41-65. 
nalne umożliwiające podmiotom społecznym określone formy współdziałania i współrządzenia w publicznym procesie decyzyjnym ${ }^{18}$. Obywatele i ich organizacje są postrzegani jako partnerzy rządzących, którzy umożliwiają im udział w procesie politycznym ze względu na zasadnicze znacznie legitymizacji społecznej dla instytucji władzy publicznej ${ }^{19}$.

\section{Governance a model demokracji}

Koncepcja governance jest przede wszystkim łączona z modelem demokracji partycypacyjnej i deliberacyjnej ${ }^{20}$, zakładającej bezpośredni udział obywateli $\mathrm{w}$ publicznym procesie decyzyjnym $\mathrm{w}$ powiązaniu $\mathrm{z}$ urzeczywistnieniem zasady pomocniczości. Administracja pomaga rozwiązywać problemy zbiorowe przy udziale zainteresowanych jednostek, grup i ich organizacji, które są traktowane jako współdecydenci i współkreatorzy dobra wspólnego, a nie tylko dostarczający głosów wyborcy czy wyręczający urzędników wolontariusze ${ }^{21}$. Przyjęcie koncepcji współrządzenia może też być efektem decyzji politycznej wynegocjowanej z partnerami społecznymi w ramach klasycznej większościowej demokracji liberalnej (np. przypadek Irlandii na początku lat $90 . \mathrm{XX}$ w.). Generalnie jednak wskazuje się, na elitarność demokracji liberalnej, a jej przejawem i słabością jest „brak możliwości równego, ciągłego i pełnego uczestnictwa obywateli w podejmowaniu decyzji zbiorowych"22. Było to szczególnie widoczne w warunkach kształtowania się młodych demokracji krajów Europy Środkowo-Wschodniej, w tym Polski, gdzie „elity solidarnościowe (...) realizowały transformację bez aktywnego udziału społeczeństwa" ${ }^{23}$. Wynikało to w dużym stopniu ze świadomego podejścia rządzących, obawiających się, że silni partnerzy społeczni będą utrudniać wprowadzanie reform społeczno-gospodarczych.

W rezultacie w Polsce można obserwować prawie wszystkie wady demokracji liberalnej, takie jak:

18 J. Hausner, Governance i jego konceptualne podstawy [w:] Współzarządzanie publiczne, S. Mazur (red.), Warszawa 2015, s. 25.

19 M. Oramus, Analiza neoweberowskiego paradygmatu zarzadzania publicznego [w:] Neo-weberyzm w zarzadzaniu publicznym. Od modelu do paradygmatu?, S. Mazur (red.), Warszawa 2016, s. 158-159.

20 B. Sadowska, L. Węsierska-Chyc, Partnerstwo jako nowa instytucja demokracji lokalnej, „Ekonomia Społeczna” 2014, nr 1, s. 12.

21 H. Izdebski, Od administracji publicznej do public governance, „Zarządzanie Publiczne" 2007, nr 1, s. 15-17 oraz cyt. tamże H.C. Boyte, Reframing democracy: governance, civic agency, and politics, „Public Administration Review” 2005, no. 5.

22 T. Piróg, Dialog obywatelski w perspektywie socjologicznej. Mity i realia dobrego rządzenia, Kraków 2016, s. 35.

23 E. Olczyk, Łabędzi śpiew prawicy, wywiad z Piotrem Marciniakiem, „Rzeczpospolita”, Plus Minus 2017, nr 8, s. 14. 
- nadmierna dominacja partii politycznych w połączeniu z innymi negatywnymi zjawiskami, określanymi jako kapitalizm polityczny i korupcja polityczna,

- dominacja silnych, partykularnych grup interesu, które za pomocą praktyk korporatywistycznych lub lobbingowych zapewniają realizację swoich interesów kosztem dobra wspólnego, nie mając do tego dodatkowo demokratycznego mandatu,

- elitarność i oligarchizacja demokracji liberalnej łącząca się z jej nietransparentnością $\mathrm{w}$ postaci niewidzialnej władzy polityków, którzy podejmują decyzje zakulisowo poza kontrolą demokratycznej opinii publicznej ${ }^{24}$.

Ponadto rzeczywista demokracja wymaga angażowania się w nią aktywnych obywateli, tymczasem czynniki mające swoje źródła jeszcze w okresie PRL przyczyniły się do bierności obywatelskiej Polaków oraz nieumiejętności artykulacji interesów politycznych i społecznych po 1989 r. ${ }^{25}$ Specyfika systemu komunistycznego doprowadziła do zaniku spontanicznego życia społeczno-politycznego. Tendencje te zostały wzmocnione, gdy po krótkim okresie „festiwalu Solidarności” nastąpiła dezintegracja świeżo zadzierzgniętych więzi społecznych spowodowana traumą stanu wojennego. Czynniki te przyczyniły się do utrzymania się zjawiska próżni socjologicznej zaobserwowanej w okresie realnego socjalizmu ${ }^{26}$.

W efekcie umocnienia się „kultury nieufności” Polacy zaczęli co najmniej ambiwalentnie traktować struktury społeczne i organizacyjne nieoparte jedynie na więziach rodzinnych i/lub towarzyskich. Spowodowało to, że ukształtował się tzw. negatywny spajający kapitał społeczny, a nie pozytywny kapitał pomostowy sprzyjający międzygrupowej komunikacji i równocześnie ponadgrupowej socjalizacji oraz otwartości w relacjach $\mathrm{z}$ innymi. $\mathrm{W}$ konsekwencji był to jeden z czynników prowadzących do trudności w zakorzenieniu społecznym partii politycznych w Polsce, a jednocześnie negatywnego ich postrzegania. $\mathrm{W}$ rezultacie partie polityczne nie tworzyły się w naturalny sposób oddolnie, ale odgórnie, opierając się na powiązaniach towarzyskich i hierarchicznych oraz „wodzowskim” przywództwie. Podobne trudności w rozwoju miały inne organizacje społeczne, związki zawodowe, a w szczególności organizacje pozarządowe, które aby realizować swoje cele, musiały wchodzić w klientelistyczne relacje z elitami politycznymi.

24 N. Bobbio, Future of democracy, Minneapolis 1987, s. 34, za: D. Zalewski, Procesy partycypacji i deliberacji a Wojewódzkie i Powiatowe Rady Zatrudnienia [w:] Wybrane instytucje demokracji partycypacyjnej w polskim systemie politycznym, Warszawa 2008, J. Sroka (red.), s. 145-146.

25 Por. T. Piróg, Dialog obywatelski..., s. 154-165

26 Por. S. Nowak, System wartości społeczeństwa polskiego, „Studia Socjologiczne” 1979, nr 4, s. 155-173. 
Tymczasem otwarcie demokracji liberalnej na partycypację powinno przyczynić się do ograniczenia jej słabości także w perspektywie Polski. Wskazuje się, że rozwijanie modelu demokracji partycypacyjnej ${ }^{27}$ :

- rozwija postawy i umiejętności obywatelskie, czyniąc system bardziej demokratycznym,

- przyczynia się do rozwoju potencjału ludzi i wzmacnia ducha obywatelskiego zaangażowania,

- jest lekarstwem na alienację - pozwala doświadczać wolności i nabierać poczucia kontroli

- nad własnym życiem i poczucia przynależności do wspólnoty,

- legitymizuje decyzje władz i stabilizuje system,

- chroni ludzką wolność i podmiotowość - czyni działania władz bliższymi ludzkich pragnień i oczekiwań,

- jest instrumentem odzyskiwania wpływu przez tych, którzy są pozbawieni władzy,

- jest rzeczywistą koniecznością - we współczesnym złożonym społeczeństwie nie sposób rządzić bez przyzwolenia rządzonych.

$\mathrm{W}$ tej perspektywy rządzenie i władza są traktowane jako w miarę równoprawna relacja dwustronna między rządzącymi i obywatelami oraz reprezentującymi ich organizacjami, $\mathrm{w}$ ramach której różne podmioty istniejące w obrębie społeczeństwa mogą uczestniczyć w podejmowaniu decyzji dotyczących ich potrzeb i dążeńn ${ }^{28}$. Należy ponadto podkreślić, że rzeczywista legitymizacja władzy nie następuje jedynie po ustanowieniu instytucjonalnych warunków partycypacji, czyli przyjęciu procedur umożliwiających konsultacje społeczne, ale w drodze rzeczywistej partycypacji i deliberacji polegającej na dochodzeniu do konsensusu, przy czym według zwolenników teorii wyboru publicznego, dialog jest dopuszczalny „w celu uzgodnienia interesów i osiągnięciu rozwiązania, na które wszyscy są w stanie się zgodzić bez zmiany na gorsze własnego położenia ${ }^{29}$.

Z drugiej strony pojawiają się argumenty kwestionujące efektywność partycypacji społecznej oraz uwidoczniające jej negatywne skutki, wskazujące, że $\mathrm{e}^{30}$ :

27 N.C. Roberts, Direct citizen participation: challenges and dilemmas [w:] The age of direct citizen participation, N.C. Roberts, M.E. Sharp (eds.), Armonk-New York 2008, za: T. Kaźmierczak, Partycypacja publiczna: pojęcie, ramy teoretyczne [w:] Partycypacja publiczna. O uczestnictwie obywateli w życiu wspólnoty lokalnej, A. Olech (red.), Warszawa 2011, s. 94-95.

28 M.M. Wiszowaty, Społeczna partycypacja w procesie politycznym a prawowitość władzy państwowej (grupy interesu, konsultacje społeczne, lobbing) [w:] Prawowitość władzy państwowej, M. Masternak-Kubiak, A. Młynarska-Sobaczewska, A. Preisner (red.), Wrocław 2014, s. 335.

29 D. Miller, Demokracja debatujaca a teoria wyboru publicznego [w:] Przyszłość demokracji: wybór tekstów, P. Śpiewak (red.), Warszawa 2005, s. 229-254.

30 N.C. Roberts, Direct citizen..., s. 95. 
- opiera się na fałszywym poglądzie co do natury ludzkiej - w istocie ludzie są irracjonalni, egoistyczni i pasywni, nie można im także ufać w sprawach publicznych,

- jest nieefektywna - nie ma możliwości czasowych, technicznych i finansowych, żeby masowo stosować zasady demokracji partycypacyjnej, ponadto przeciętny człowiek nie jest w stanie zrozumieć złożonych procesów zarządzania sprawami i instytucjami publicznymi,

- jest politycznie naiwna - rządzenie powinno być powierzone dobrze przygotowanej, kompetentnej elicie,

- jest nierealistyczna - większość obywateli nie posiada niezbędnych zasobów (czasu, pieniędzy, wiedzy i umiejętności), z kolei ludzie zajęci zarabianiem na życie nie są zainteresowani uczestnictwem (z wyjątkiem niewielu),

- jest destrukcyjna - zbyt silne obywatelskie zaangażowanie podgrzewa konflikt polityczny i jest dysfunkcjonalne,

- jest niebezpieczna - może prowadzić do totalitaryzmu (co pokazał $\mathrm{XX}$ w.), a ludzie o niskim statusie socjoekonomicznym często przyjmują postawy antydemokratyczne i autorytarne, co może grozić przyjmowaniem tego typu rozwiązań.

Do powyższych zarzutów kwestionujących zalety partycypacji jako takiej dołącza się krytyczne uwagi dotyczące roli organizacji społecznych w demokracji. Zauważa się, że brak im mandatu demokratycznego i reprezentatywności do współudziału w podejmowaniu decyzji dotyczących ogółu obywateli, są uzależnione politycznie, towarzysko i finansowo od elit władzy, a ponadto brak im demokracji wewnętrznej oraz poparcia lokalnych społeczności, by skutecznie reprezentować ich interesy. Dlatego też należy realistycznie oceniać udział organizacji społecznych we współrządzeniu publicznym ${ }^{31}$.

Z kolei zwolennicy demokracji partycypacyjnej zwracają uwagę, że administracja kierująca się podejściem governanace powinna być responsywna, czyli m.in. otwarta na społeczeństwo poprzez partycypację publiczną, konsensus i inkluzje społeczną. Decyzje podejmowane przez administracje publiczna powinny odpowiadać pluralistycznym interesom. Partycypacja na poziomie administracji musi gwarantować, że stanowienie prawa polegające na implementacji przyjętych rozwiązań legislacyjnych w aktach wykonawczych odbywa się z udziałem przedstawiciel tych pluralistycznych interesów uczestniczących $\mathrm{w}$ doprecyzowywaniu polityk publicznych i ich artykułowaniu oraz uzgadnianiu ${ }^{32}$. Rolą administracji powinno być pośredniczenie pomiędzy obywatelami i interesami grup, aby były realizowa-

31 Por. T. Piróg, Dialog obywatelski..., s. 60-83.

32 M. Stępień, Responsywna administracja publiczna, Toruń 2008, s. 76. Autor ten powołuje się na R. Stewarda, który stwierdza, że nie ma transcendentnego interesu publicznego, ale są jedynie różne interesy jednostek i grup, The reformation of American administrative law, „Harvard Law Review” 1975, vol. 88, s. 1667-1813. 
ne wspólnie podzielane wartości. Zwiększenie responsywności koresponduje ze wzrostem zaufania obywateli do rządzących. Jednakże także w tym przypadku pojawia się dylemat związany $\mathrm{z}$ tym, jak można uczestniczyć bezpośrednio w działaniach tak bardzo rozległych i skomplikowanych systemów współczesnej administracji.

\section{Relacje między administracją publiczną i trzecim sektorem po 1989 r.}

Organizacje pozarządowe zyskały nieskrępowaną możliwość działalności po przełomie ustrojowym w 1989 r. Podstawy prawne dawały Prawo o stowarzyszeniach i ustawa o fundacjach uchwalone jeszcze w latach 80., które zostały poddane nowelizacjom dostosowujących je do standardów państwa demokratycznego i pluralistycznego. Pojawily się zatem rozwiązania prawne umożliwiające działalność organizacjom obywatelskim, jednakże brak było oferty skierowanej do organizacji pozarządowych, a państwo i NGOs działały niejako obok siebie. Pewne możliwości współpracy na poziomie lokalnym dawała ustawa o pomocy społecznej z 1990 r., która przewidywała udział organizacji społecznych w realizacji pomocy społecznej we współpracy z samorządami lokalnymi. W latach 1993-1997 pojawily się projekty aktów prawnych regulujących współpracę organizacji z administracją publiczną (pierwsze próby uregulowania działalności pożytku publicznego). Ważne dla organizacji pozarządowych było też wpisanie zasad społeczeństwa obywatelskiego, pomocniczości i dialogu społecznego do nowej Konstytucji z 1997 r. Kolejne lata przyniosły niekorzystne dla organizacji pozarządowych uregulowania w ustawie o finansach publicznych oraz reformę administracji publicznej, które spowodowały likwidację dotychczasowych form współpracy i rozproszenie kompetencji na różne szczeble samorządu terytorialnego. Niestety nie uregulowano statusu organizacji pozarządowych jako tzw. piątej reformy (po administracyjnej, emerytalnej, zdrowotnej i edukacyjnej), która według Z. Woźniaka powinna opierać się na zasadach partnerstwa, prawa do współdefiniowania zadań publicznych, pomocniczości, efektywności społecznej i ekonomicznej oraz jawności ${ }^{33}$.

Przełomem $\mathrm{w}$ relacjach organizacji pozarządowych $\mathrm{z}$ administracją publiczną (a szczególnie z administracją samorządową) było uchwalenie ustawy o działalności pożytku publicznego i wolontariacie w 2003 r., która dała instytucjonalne podstawy realizacji koncepcji governance i zapewniła organizacjom pozarządowym udział w wykonywaniu zadań publicznych. Następnie wejście do UE zobowiązało instytucje publiczne do prowadzenia programów aktywizacji beneficjentów środków unijnych. Początkowo jednak trudno było uznać wzajemne relacje za rzeczywiste partnerstwo, gdyż

33 Z. Woźniak, Między rywalizacja a partnerstwem, Bariery wspólpracy władz publicznych z organizacjami pozarządowymi [w:] Samoorganizacja społeczeństwa polskiego - trzeci sektor, P. Gliński i in. (red.), Warszawa 2002, s. 102-103. 
np. jedynie połowa programów współpracy samorządów z organizacjami była z nimi konsultowana ${ }^{34}$. Wzmocnienie roli organizacji pozarządowych w lokalnym governance nastąpiło dzięki zmianom w ustawie uchwalonych 2010 r., które wprowadziły obligatoryjność konsultacji z organizacjami pozarządowymi m.in. w związku z przyjmowaniem przez jednostkę samorządu terytorialnego rocznego programu współpracy z organizacjami pozarządowymi. Niestety ustawa nie określa procedury przeprowadzenia konsultacji na poziomie samorządowym i praktyki w tym zakresie kształtują się odrębnie w każdej wspólnocie samorządowej. Krytyka poziomu otwartości i możliwości prowadzenia dialogu wpływa na decyzje polityczne rządzących. Częściej ma to miejsce na poziomie krajowym niż na poziomie regionalnym i lokalnym ${ }^{35}$.

Formy realizacji koncepcji governance w Polsce to konsultacje społeczne poprzedzające działania i rozstrzygnięcia administracji publicznej ${ }^{36}$ :

- konsultacje adresowane do całego społeczeństwa lub do danej społeczności lokalnej w celu poznania jak najszerszej opinii na dane zagadnienie,

- wysłuchanie publiczne,

- konsultacje z mieszkańcami gminy powiatu i województwa na podstawie ustaw o samorządzie gminnym, powiatowym i wojewódzkim,

- konsultacje „branżowe”, kierowane do określonych organizacji ze względu na ich związek z dziedziną, której dotyczy regulacja, lub polegające na zaproszeniu danej grupy interesu do konsultacji społecznych przez władze,

- konsultowanie projektów aktów prawnych przez Radę Ministrów (na podstawie Regulaminu pracy Rady Ministrów),

- konsultowanie projektów przez partnerów społecznych w ramach dawnej Komisji Trójstronnej, a obecnie Radę Dialogu Społecznego oraz Radę Pożytku Publicznego.

Ponadto mają miejsce niestandardowe formy konsultacji społecznych, takie jak ${ }^{37}$ :

- konsultacje elektroniczne za pomocą poczty elektronicznej czy poprzez zamieszczenie $\mathrm{w}$ internecie kwestionariusza z pytaniami,

34 J. Schmidt, Rozwój organizacji pozarządowych. Teoria i praktyka, Warszawa 2012, s. 84 i cyt. tamże M. Gumkowska, J. Herbst, Podstawowe fakty o organizacjach pozarzadowych. Raport z badania, Warszawa 2006, s. 15.

35 K. Wódz, A. Napiontek, Negocjowana demokracja, czyli europejskie governance po polsku [w:] Społeczeństwo obywatelskie. Między ideq a praktyką, A. Kościański, W. Misztal (red.), Warszawa 2008, s. 94.

36 M. Kulesza, D. Sześciło, Polityka administracyjna i zarzadzanie publiczne, Warszawa 2013, s. 120.

37 M. Pyka, Poradnik „Dobrych Praktyk Konsultacji Społecznych”, Warszawa 2011, s. 46-48, za: M. Kulesza, D. Sześciło, Polityka administracyjna..., s. 123. 
- panele obywatelskie obejmujące badania prowadzone na reprezentatywnej grupie mieszkańców,

- konsultacje SMS-owe - wiadomości wysyłane przez gminy do mieszkańców dotyczące najważniejszych wydarzeń i zbierające opinie od mieszkańców gminy.

Inne formy partycypacji to tworzenie rad, komitetów i zespołów z udziałem przedstawicieli organizacji pozarządowych, grup interesu, a także instytucji naukowych oraz udział obywateli w kształtowaniu budżetu gminnego (budżet partycypacyjny).

Konsultacje społeczne umożliwiają włączanie partnerów społecznych reprezentujących szerokie spektrum społeczne do udziału w publicznym procesie decyzyjnym, w którym razem z przedstawicielami władz publicznych rozstrzygają ważne kwestie społeczne ${ }^{38}$. Konsultacje społeczne są elementem demokracji partycypacyjnej, jeśli zasięganie opinii w trakcie tworzenia prawa prowadzi do dochodzenia do wspólnych uzgodnień w efekcie wspólnej dyskusji ${ }^{39}$. Podstawowym problemem, jeśli chodzi o konsultacje w polskich realiach, jest ich opiniodawczy charakter, nawet jeśli ich przeprowadzenie jest obligatoryjne, zatem rządzący nie są nimi związani, natomiast partycypacja to realny wpływ na treść powziętych decyzji. Ponadto często rządzący „legitymizują” powzięte decyzje, informując o przeprowadzonych konsultacjach, ale nie odnoszą się do krytycznych opinii konsultowanych, często też konsultowani mają zbyt mało czasu na przedstawienie opinii ${ }^{40}$.

Dlatego też konsultacje i inne formy partycypacji społecznej często stanowią fasadę, a rządzący nie są gotowi do włączenia obywateli i ich organizacji do współdecydowania ${ }^{41}$. Świadomość tego mają też sami konsultowani, którzy często wybierają bardziej nieformalne metody wpływu na decyzje decydentów, takie jak bezpośrednie kontakty z przedstawicielami administracji rządowej i samorządowej, lobbing na poziomie parlamentu, rządu i wobec radnych gmin, powiatów i województw. Pozytywne efekty tych kontaktów zależą w dużym stopniu od oceny pozycji i znaczenia organizacji społecznych na arenie krajowej lub lokalnej. Ponadto finansowe uzależnienie niektórych organizacji pozarządowych od władz lokalnych i regionalnych sprzyja postawom uległości wobec rządzących. Badania przeprowadzone wśród organizacji pozarządowych na szczeblu powiato-

38 A. Krajewska, Konsultacje społeczne w praktyce. Studium dwóch przypadków [w:] Organizacje pozarządowe. Dialog obywatelski. Polityka państwa, M. Rymsza (red.), Warszawa 2008, s. 127.

39 D. Długosz, J. Wygnański, Obywatele współdecydują. Przewodnik po partycypacji społecznej, Stowarzyszenie na rzecz Forum Inicjatyw Pozarządowych, Warszawa 2005, s. 21.

40 Przejrzystość procesu stanowienia prawa, raport z realizacji projektu „Społeczny monitoring procesu stanowienia prawa”, Fundacja Batorego, Warszawa 2008, s. 59.

41 B. Sadowska, L. Węsierska-Chyc, Partnerstwo jako nowa instytucja..., s. 12, 18. 
wym wskazują, że promotorami współrządzenia, którym zależy na realnej partycypacji w procesach decyzyjnych, są organizacje niezależne finansowo od dotacji przyznawanych przez decydentów lub korzystające $\mathrm{z}$ tych dotacji w niewielkim zakresie swoich budżetów ${ }^{42}$.

\section{Zakończenie}

Governance (współrządzenie) to skuteczniejsze działanie administracji publicznej poprzez umożliwienie partnerom społecznym udziału w formułowaniu i implementacji polityk publicznych. Pluralistyczne oddziaływanie na organy administracji publicznej ogranicza zarówno dyskrecjonalną władzę biurokracji, jak i możliwość uzyskania nadmiernego wpływu na jej decyzje przez pojedyncze wpływowe grupy interesu. Zwolennicy podejścia pluralistycznego uważają, że organizacje publiczne, jakimi są agendy administracji, muszą często nie tylko respektować wartości i interesy różnorodnego otoczenia społecznego, ale zabiegając o poparcie ważnych grup interesu, urzędnicy zmuszeni są brać pod uwagę, przynajmniej częściowo, różne, nierzadko rozbieżne interesy i oczekiwania szerszych grup społeczeństwa ${ }^{43}$.

W efekcie uzyskuje się skuteczniejszą politykę publiczną, co stanowi klucz dla doskonalszego rozwoju społeczno-gospodarczego oraz prowadzi do upodmiotowienia zorganizowanego społeczeństwa obywatelskiego w realizacji zadań publicznych. Umożliwić to powinno przejście od konfrontacji do dialogu i koncyliacji, wzmocnienie kapitału społecznego dzięki wzrostowi zainteresowania opinii publicznej dla postulatów podnoszonych przez organizacje społeczne. Barierą w realizacji powyższych koncepcji jest etatystyczno-paternalistyczne podejście do roli organizacji pozarządowych w Polsce. Politycy i zależna od nich administracja rządowa $\mathrm{z}$ dystansem podchodzą do udziału podmiotów społecznych w podejmowaniu decyzji i obawiają się niezależnych ocen. Konsultacje z podmiotami społecznymi (NGO, środowiska akademickie) są blokowane lub mają charakter fasadowy (brak sprawczości, krótkie terminy). Dlatego też zachowane powinny być pewne standardy prowadzenia konsultacji jako stałego elementu działań administracji, a nie spełnianie jedynie wymogów formalnej procedury. Rzeczywiste, a nie fasadowe współrządzenie doprowadzi do ograniczania arbitralności podejmowanych decyzji i rozstrzygnięć normatywnych, które będą skonfrontowane $\mathrm{z}$ oczekiwaniami i postulatami wysuwanymi przez zainteresowane nimi grupy i środowiska najlepiej zorientowane $\mathrm{w}$ dziedzinach, którą mają być regulowane.

42 T. Piróg, Dialog obywatelski..., s. 262-263.

43 S. Mazur, Władza dyskrecjonalna wysokich urzędników publicznych. Perspektywa nowego instytucjonalizmu, Kraków 2011, s. 211. 
Blicharz J., Rola partnerstwa trójsektorowego $w$ ramach nowego zarządzania publicznego a problem biurokracji [w:] Biurokracja, J. Łukaszewicz (red.), Rzeszów 2006.

Bobbio N., Future of demoracy, Minneapolis 1987.

Boyte H.C., Reframing democracy: governance, civic agency, and politics, „Public Administration Review" 2005, no. 5.

Długosz D., Wygnański J., Obywatele współdecydują. Przewodnik po partycypacji społecznej, Stowarzyszenie na rzecz Forum Inicjatyw Pozarządowych, Warszawa 2005.

Dunsire A., Przechylanie szal: autopoieza i rzadzenie, „Zarządzanie Publiczne” 2007, $\mathrm{nr} 2$.

Izdebski H., Od administracji publicznej do public governance, „Zarządzanie Publiczne" 2007, nr 1.

Graniszewski L., Udział aktorów pozapaństwowych w rządzeniu transnarodowym, „Studia Politologiczne” 2015, vol. 27.

Gumkowska M., Herbst J., Podstawowe fakty o organizacjach pozarzadowych. Raport z badania, Warszawa 2006.

Hausner J., Governance i jego konceptualne podstawy [w:] Współzarządzanie publiczne, S. Mazur (red.), Warszawa 2015.

Izdebski H., Introduction to public administration and administrative law, Warszawa 2006.

Kaźmierczak T., Partycypacja publiczna: pojęcie, ramy teoretyczne [w:] Partycypacja publiczna. O uczestnictwie obywateli w życiu wspólnoty lokalnej, A. Olech (red.), Warszawa 2011.

Kjaer A.M., Governance and the urban bureaucracy [w:] J. Davies, D.L. Imbroscio (eds.), Theories of urban politics, Sage Publications Ltd 2009.

Krajewska A., Konsultacje społeczne w praktyce. Studium dwóch przypadków [w:] Organizacje pozarządowe. Dialog obywatelski. Polityka państwa, M. Rymsza (red.), Warszawa 2008.

Kulesza M., Sześciło D., Polityka administracyjna i zarządzanie publiczne, Warszawa 2013.

Małecka-Łyszczek M., Partycypacja w ramach public governance [w:] Partycypacja społeczna w samorzadzie terytorialnym, B. Dolnicki (red.), Warszawa 2014.

Mazur S., Władza dyskrecjonalna wysokich urzędników publicznych. Perspektywa nowego instytucjonalizmu, Kraków 2011.

Miller D., Demokracja debatujaca a teoria wyboru publicznego [w:] Przyszłość demokracji: wybór tekstów, P. Śpiewak (red.), Warszawa 2005.

Nowak S., System wartości społeczeństwa polskiego, „Studia Socjologiczne” 1979, nr 4.

Olczyk E., Łabędzi śpiew prawicy, wywiad z Piotrem Marciniakiem, „Rzeczpospolita”, Plus Minus 2017, nr 8.

Oramus M., Analiza neoweberowskiego paradygmatu zarzadzania publicznego [w:] Neo-weberyzm w zarzadzaniu publicznym. Od modelu do paradygmatu?, S. Mazur (red.), Warszawa 2016. 
Peters B.G., Pierre J., Governance without government? Rethinking public administration, "Journal of Public Administration Research \& Theory" 1998, vol. 8, no. 2.

Piróg T., Dialog obywatelski w perspektywie socjologicznej. Mity i realia dobrego rzadzenia, Kraków 2016.

Podgórecki A., Teoria społeczeństwa polskiego [w:] Przełom i wyzwanie, A. Sułek, W. Wincławski (red.), Warszawa-Toruń 1991.

Przejrzystość procesu stanowienia prawa, raport z realizacji projektu „Społeczny monitoring procesu stanowienia prawa” Fundacja Batorego, Warszawa 2008.

Pyka M., Poradnik „Dobrych Praktyk Konsultacji Społecznych”, Warszawa 2011.

Rajca L., Reformy inspirowane koncepcja wspótrządzenia (governance) w Anglii [w:] Wspótczesne wyzwania administracji rządowej i samorządowej, D. Plecka (red.), Toruń 2013.

Roberts N.C., Direct citizen participation: challenges and dilemmas [w:] The age of direct citizen participation, N.C. Roberts, M.E. Sharp (eds.), Armonk-New York 2008.

Rotko J., Ekologiczna polityka podatkowa w RFN [w:] Księga Jubileuszowa Profesora Marka Mazurkiewicza: studia $z$ dziedziny prawa finansowego, prawa konstytucyjnego i ochrony środowiska, R. Masalski (red.), Wrocław 2001.

Sadowska B., Węsierska-Chyc L., Partnerstwo jako nowa instytucja demokracji lokalnej, „Ekonomia Społeczna” 2014, nr 1.

Schmidt J., Rozwój organizacji pozarządowych. Teoria i praktyka, Warszawa 2012.

Stępień M., Responsywna administracja publiczna, Toruń 2008.

Steward R., The reformation of American administrative law, „Harvard Law Review" 1975, vol. 88.

Supernat J., Administracja publiczna, governance i nowe publiczne zarzadzanie [w:] Prawna działalność instytucji społeczeństwa obywatelskiego, J. Blicharz, J. Boć, (red.), Wrocław 2009.

Supernat J., Administracja publiczna w świetle koncepcji New Public Management [w:] Jednostka, państwo, administracja - nowy wymiar. Międzynarodowa Konferencja Naukowa, Olszanica 23-26 maja 2004 r., E. Ura (red.), Rzeszów 2004.

Wiszowaty M.M., Społeczna partycypacja $w$ procesie politycznym a prawowitość władzy państwowej (grupy interesu, konsultacje społeczne, lobbing) [w:] Prawowitość władzy państwowej, M. Masternk-Kubiak, A. Młynarska-Sobaczewska, A. Preisner (red.), Wrocław 2014.

Woźniak Z., Między rywalizacją a partnerstwem. Bariery współpracy władz publicznych z organizacjami pozarządowymi [w:] Samoorganizacja społeczeństwa polskiego - trzeci sektor, P. Gliński i in. (red.), Warszawa 2002.

Wódz K., Napiontek A., Negocjowana demokracja, czyli europejskie governance po polsku [w:] Społeczeństwo obywatelskie. Między ideq a praktyką, A. Kościański, W. Misztal (red.), Warszawa 2008.

Zalewski D., Procesy partycypacji i deliberacji a Wojewódzkie i Powiatowe Rady Zatrudnienia [w:] Wybrane instytucje demokracji partycypacyjnej w polskim systemie politycznym, J. Sroka (red.), Warszawa 2008.

Zybała A., Polski umysł zamknięty, „Rzeczpospolita” 2016, nr 223. 
Streszczenie

Artykuł dotyczy zastosowania koncepcji governance (współrządzenia) w realiach polskiego systemu politycznego. Autor analizuje formy udziału obywateli i ich organizacji w podejmowaniu decyzji przez administrację publiczną, szczególnie w oparciu o koncepcję Nowego Zarządzania Publicznego i governance (współrządzenia). Następnie analizowane jest znaczenie realizacji koncepcji governance w kontekście istniejących modeli demokracji, a szczególnie demokracji liberalnej i partycypacyjnej. Ostatnią częścią artykułu jest ukazanie instytucjonalizacji koncepcji governance w polskim prawie oraz w praktyce życia społeczno-politycznego.

Słowa kluczowe: współrządzenie, organizacje pozarządowe, konsultacje społeczne, dialog obywatelski, administracja publiczna

\section{The Participation of Non-Governmental Organisations in Public Governance in Poland}

Abstract

The article focuses on the application of the concept of governance in the realities of the Polish political system. The author analyses the forms of participation of citizens and their organisations in the decision-making of public administrations, particularly based on the notion of New Public Management and Governance. Further, he analyses the importance of implementing the concept of governance in the context of the existing models of democracy, especially liberal and participatory democracy. The last part of the article presents the institutionalisation of the notion of Governance in Polish law and practice of socio-political life.

Keywords: governance, non-governmental organisations, public consultation, civic dialogue, public administration 